\title{
Effect of Processing Methods on Physico-Chemical Properties, Sensory Evaluations and Storage Studies of Cauliflower (Brassica oleracea L. var. botrytis) Pickle
}

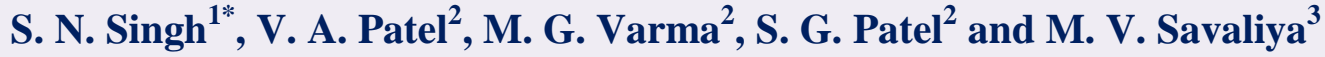 \\ ${ }^{1}$ Department of Processing \& Food Engineering, ${ }^{2}$ Department of Basic Science \& Basic \\ Engineering, '3 (Agriculture Engg.), College of Agricultural Engineering \& Technology, \\ Navsari Agricultural University, Dediapada, India \\ *Corresponding author
}

\begin{tabular}{|l|}
\hline Ke y w o r d s \\
Cauliflower \\
(Brassica oleracea \\
$\begin{array}{l}\text { L. var. botrytis), } \\
\text { pickle, Physico- } \\
\text { chemical properties, } \\
\text { Sensory } \\
\text { evaluations, Storage } \\
\text { studies }\end{array}$ \\
\hline Article Info \\
\hline $\begin{array}{l}\text { Accepted: } \\
\text { 12 December } 2020 \\
\text { Available Online: } \\
\text { 10 January } 2021\end{array}$ \\
\hline
\end{tabular}

Cauliflower (Brassica oleracea L. var. botrytis) is an excellent source of nutrient and containing low calorie, low fat and zero cholesterol content. Prolonged cooking of cauliflower destroys majority of vitamins and it is associated with bad smell. Perishable nature of cauliflower forces the farmers to sell it at a very low price during the glut season. In this situation, pickle is one of the oldest and most successful methods for preservation of cauliflower. The cauliflower pickles were prepared by using three types cauliflowers i.e. fresh (raw), boiled, fried and three $\left(\mathrm{B}_{1}, \mathrm{~B}_{2}\right.$ and $\left.\mathrm{B}_{3}\right)$ different proportions of spices with two replications. The prepared cauliflower pickles were packaged in air tight glass bottle. The different physico-chemical properties of cauliflower pickle such as moisture content, protein, vitamin $\mathrm{C}$, ash content, $\mathrm{pH}$ and TSS were studied. The maximum values of moisture content $58.50 \%\left(\mathrm{~T}_{5}\right)$, protein contents $5.86 \mathrm{~g} / 100 \mathrm{~g}\left(\mathrm{~T}_{8}\right)$, Vitamin $\mathrm{C}$ content 97.60 $\mathrm{mg} / 100 \mathrm{~g}\left(\mathrm{~T}_{6}\right)$, ash content $3.92 \%\left(\mathrm{~T}_{9}\right)$ respectively and minimum values of moisture content $40.56 \%\left(\mathrm{~T}_{7}\right)$, protein contents $4.97 \mathrm{~g} / 100 \mathrm{~g}\left(\mathrm{~T}_{1}\right)$, Vitamin C content $91.37 \mathrm{mg} / 100 \mathrm{~g}$ $\left(\mathrm{T}_{9}\right)$, ash content $0.91 \%\left(\mathrm{~T}_{1}\right)$ respectively. Increasing trend of $\mathrm{pH}$ and TSS values were observed with increasing storage period. The significant variations were observed for appearance, aroma, texture, taste, colour and overall acceptability. It also shows the sensory values for all properties were more than 5.00 up to 2 months storage periods. On the basis of storage studied of 0 months, 1 month, 2 months and 3 months on colour change, off flavour properties, texture and visual fungal growth of cauliflower pickles, the treatments $\mathrm{T}_{8}, \mathrm{~T}_{9}, \mathrm{~T}_{6}$ and $\mathrm{T}_{5}$ were observed better quality.

\section{Introduction}

Cauliflower (Brassica oleracea L. var. botrytis) is an important major winter vegetables crop extensively grown worldwide including India. It is an annual plant that reproduces by seed and only the head is eaten, the edible white flesh sometimes called "curd". It has high nutritional value and it is known as one of the healthiest plants on the planet. It is an excellent source of dietary fibers, vitamins $\mathrm{C}, \mathrm{K}$ and vitamins of the $\mathrm{B}$ 
group and minerals such as manganese, potassium and magnesium. Its white inflorescence as it is low calorie, low fat, zero cholesterol content (Madavi and Bhajbhuje, 2014). Its role in the diet is also thought to be significant in preventing cancer, heart disease and immune system functioning (Nishina et aI., 1991; Sauberlich, 1994; Wargovich, 2000 and Kaur and Kapoor, 2001). Some researchers state that its quality is related to stability of its fatty acids (Scalzo et al., 2007; Sharma et al., 2005). The storage-life is approximately 7 to 10 days at $5^{\circ} \mathrm{C}$. Storage for more than 3 weeks or at temperatures higher than $0^{\circ} \mathrm{C}$ results in poor visual and sensory quality (Hardenburg et al., 1986; Suslow and Cantwell, 1998; DeEll et al., 2003; Scalzo et al., 2007; Canan Ece Tamer, 2012).

Quality loss in fresh cauliflower includes undesirable odors, yellowing of the curd sharp increase in bitter taste, curd softening, and leaf wilting (Fjeldsenden et al., 1981; Forbes and Chapman, 1989; Berrang et al., 1990; Schonhof et al., 2004; Hodges et al., 2006; Canan Ece Tamer, 2012). Prolonged cooking of cauliflower destroys majority of vitamins and it is associated with sulphur like bad smell. Cooking of cauliflower more than 30 minutes, decreases its $75 \%$ of health benefits. In raw form, it is also mixed with green salad or its pieces are dipped into sauces. It is also used in the preparation of pickle or mixed pickle with other vegetables (Sharma et al., 2005). Perishable nature of cauliflower forces the farmers to sell it at a very low price during the glut season. In this situation, appropriate processing techniques are needed to utilize the abundant supply of cauliflower to reduce the post harvest loss and to increase the period of its availability.

Food preservation usually involves preventing the growth of fungi, bacteria or any other micro-organisms, as well as retarding the oxidation of fats that cause rancidity. Fermentation is a slow decomposition process of organic substances induced by microorganisms or enzymes that essentially convert carbohydrates to alcohols or organic acids (FAO, 1998). LAB fermented vegetables helps to enhance human nutrition with the attainment of balanced nutrition, providing vitamins, minerals, and carbohydrates (Yamano et al., 2006). Pickling along with drying and dehydration is one of the oldest food preservation techniques (USDA, ERS 2007). The pickling is basically, conversion of sugar to acid by microorganisms that are lactic acid bacteria (LAB) (Nurul and Asmah, 2012). As sugar convert to the lactic acid the condition become acidic and inhibits the growth of pathogens and other non acidic tolerant microorganisms' especially aerobic spoilage microorganisms. As a result from pickling, the vegetable will have a longer shelf life, translucent appearance, firm texture and pickle flavour.

The cauliflowers are generally mixed with ingredients like salt, spices, and vegetable oils and are set to mature in moisture less medium. Sodium chloride is one of the most commonly employed agents for food conservation, allowing considerable increase in storage time by reducing water activity (Jamshidi et. al., 2008; Arghya Mani, 2017). The optimization of pickle quality depends on maintenance of proper acidity, salt concentration, temperature and sanitary conditions. Another distinguishing characteristic is a $\mathrm{pH}$ less than 4.6 which is sufficient to kill most bacteria.

There are a number of methods for the preservation of perishable items. Pickling is one of them. It can preserve perishable foods for months. Pickles can be obtained by plain immersion of raw, fried and blanched or precooked pieces of vegetables. Antimicrobial 
herbs and spices, such as mustard seed, garlic, cinnamon or cloves, are often added. If the food contains sufficient moisture, pickling brine may be produced simply by adding dry salt. Prepared cauliflower pickles were stored in the bottle and jars (Noor et al., 2014). Pickles are mostly packed in glass bottles due to their rigidity, inertness, non-toxicity, durability, compatibility and indigenous availability.

The glass packaging imparts long shelf life to pickle due to its inertness and impermeability to moisture and gases (Gopal et al., 1985; C. Chellaram, 2015).Natural fermentation at room temperature, by lactic acid bacteria, produces the required acidity. Pickles serve as appetizers and help in digestion by aiding flow of gastric juices. Pickles are generally consumed by everyone whether a child or old, a labour, or a rich man. It makes the dish or food taste better and generally acts as appetizer (Noor et al., 2014).

The aim of this research was to determine the physico-chemical properties sensory evaluations and storage studies of cauliflower pickles having different ingredients. Because cauliflower was not utilized widespread in food industry, it is required to determine possibility of the production of cauliflower pickle as a value added product.

\section{Materials and Methods}

The fresh cauliflower and other spices ingredients were procured and collected from local market of Dediapada. The spices ingredients like salt (sodium chloride), Ginger (Zingiber officinale), Red chili, Turmeric (Curcuma longa), Cinnamon (Cinnamomum verum), Black pepper (Piper nigrum), Cardamom (Elettaria cardamom), Aniseed (Pimpinella anisum), Clove (Syzygium Aromaticum), Mustard (Brassica nigra), Vinegar (acetic acid), Mustard oil,
Sugar(monosaccharides) andGarlic (Allium sativum) were used for the preparations of pickles. Purchased spices were cleaned, dried, grind properly and packed in HDPE polythene bags for pickles preparations as per their requirement. In pickle production spices ingredients were played major role for pickle preparation. Fresh cauliflower was washed properly and cut into $2.5 \mathrm{~cm}$ long pieces. In order to inhibit enzymatic browning, they were blanched in hot water at $100^{\square}$ containing $\mathrm{NaCl}$ salt $(0.6 \%)$ for $2-3$ minutes.

\section{Treatment details and experimental design}

Different treatments details and experimental design with different combinations for preparation of cauliflower pickles were presented in Table.1.

\section{Cauliflower sample}

$\mathrm{A}_{1}=$ Fresh cauliflower pickle

$\mathrm{A}_{2}=$ Boiled cauliflower pickle

$\mathrm{A}_{3}=$ Fried cauliflower pickle

\section{Ingredients proportions}

$\mathrm{B}_{1}=250 \mathrm{~g}$ cauliflower, $40 \mathrm{~g}$ of salt, $6 \mathrm{~g}$ ginger, $6 \mathrm{~g}$ red chili powder, $5 \mathrm{~g}$ cinnamon, $3 \mathrm{~g}$ cumin, $2 \mathrm{~g}$ cardamom, $7 \mathrm{~g}$ aniseed, $2 \mathrm{~g}$ clove, $13 \mathrm{~g}$ mustard, $30 \mathrm{~g}$ vinegar, $30 \mathrm{~g}$ sugar, $100 \mathrm{ml}$ mustard oil, $6 \mathrm{~g}$ garlic.

$\mathrm{B}_{2}=250$ gm cauliflower, $45 \mathrm{~g}$ of salt, $7 \mathrm{~g}$ ginger, $8 \mathrm{~g}$ red chili powder, $6 \mathrm{~g}$ cinnamon, $4 \mathrm{~g}$ cumin, $3 \mathrm{~g}$ cardamom, $9 \mathrm{~g}$ aniseed, $3 \mathrm{~g}$ clove, $15 \mathrm{~g}$ mustard, $35 \mathrm{~g}$ vinegar, $40 \mathrm{~g}$ sugar, $100 \mathrm{ml}$ mustard oil, 10g garlic

$\mathrm{B}_{3}=250 \mathrm{gm}$ cauliflower, $50 \mathrm{~g}$ of salt, $9 \mathrm{~g}$ ginger, $9 \mathrm{~g}$ red chili powder, $8 \mathrm{~g}$ cinnamon, $5 \mathrm{~g}$ cumin, $4 \mathrm{~g}$ cardamom, $11 \mathrm{~g}$ aniseed, $4 \mathrm{~g}$ clove, $16 \mathrm{~g}$ mustard, $40 \mathrm{~g}$ vinegar, $45 \mathrm{~g}$ sugar, $100 \mathrm{ml}$ mustard oil, $12 \mathrm{~g}$ garlic 


\section{Cauliflowers pickle preparations methods}

\section{Methods for pickle preparations from fresh cauliflower}

For preparing fresh cauliflower pickles first of all collect cauliflower into the local market and then washed. After washing removal of undesirable or unnecessary material of cauliflower and cutting into small pieces into $2.5 \mathrm{~cm}$ long. Cauliflowers were blanching into water for 2-3 minutes. After blanching sun drying process were carried out for period of one hour. Mixing the ingredients into cauliflower and mix well and fried mustard oil was mixed on cauliflower. After that pickle were filled into glass jar and kept for further analysis.

\section{Methods for pickle preparations from boiled cauliflower}

For preparing fresh cauliflower pickles first of all collect cauliflower into the local market and then washed. After washing removal of undesirable or unnecessary material of cauliflower and cutting into small pieces into $2.5 \mathrm{~cm}$ long. Cauliflowers were blanching into water for 2-3 minutes. After blanching process, the cauliflower was boiled into water for 8-10 minutes. Then cauliflowers keep under sun drying for the period of one hour. Mixing the ingredients into cauliflower and mix well and fried mustard oil was mixed on cauliflower. After that pickle were filled into glass jar and kept for further analysis.

\section{Methods for pickle preparations from fried cauliflower}

For preparing fresh cauliflower pickles first of all collect cauliflower into the local market and then washed. After washing removal of undesirable or unnecessary material of cauliflower and cutting into small pieces into $2.5 \mathrm{~cm}$ long. Cauliflowers were blanching into water for 2-3 minutes. After blanching process the cauliflowers were fired into mustard oil at $100^{\square}$ up to slightly brownish color estimated time approx 5-6 minutes. After that the fried cauliflower were kept under sun drying for one hour. Mixing the ingredients into cauliflower and mix well and fried mustard oil is mixed on cauliflower. After that pickle were filled into glass jar and kept for further analysis.

\section{Process Flow Chart for Pickles Preparations}

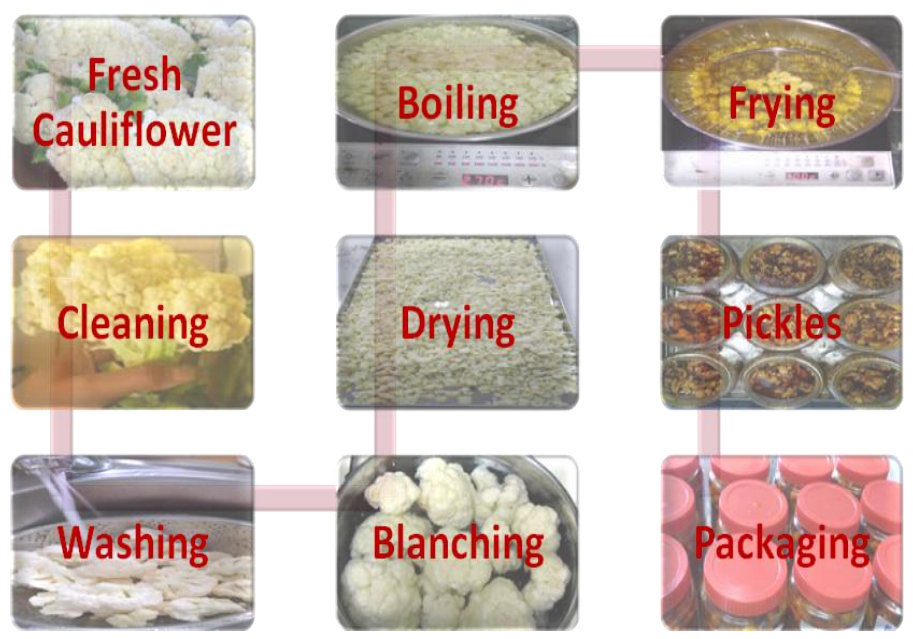




\section{Methodology used for analysis of pickle}

Moisture content, protein, vitamin $\mathrm{C}$, ash content, $\mathrm{pH}$, and Total soluble solids (TSS) of different treatments of cauliflower pickle were studied and their details methodology were as under sub headings.

\section{Moisture content}

Moisture content of cauliflower pickle was calculated hot air oven methods (AOAC 1990). The samples were kept at $105^{\square}$ for 24 hours. Calculate the moisture content on a wet weight basis using following formula,

Moisture content $(\%)=\frac{\mathrm{w} 2-\mathrm{w} 3}{\mathrm{w} 2-\mathrm{w}_{1}} \times 100$

Where,

$\mathrm{W}_{1}=$ Weigh of container

$\mathrm{W}_{2}=$ Weigh of container with sample before dry

$\mathrm{W}_{3}=$ Weigh of container with sample after dry

\section{Protein content}

The protein content of cauliflower pickle was determined by Lowry Method. In this method the reactivity of the peptide nitrogen with the copper ions under conditions and the subsequent reduction of the Folin-Ciocalteay phosphorus to hetero poly molybdenum blue by the copper catalyzed or aromatic acids.

\section{Vitamin C}

Vitamin C (also known as ascorbic acid) is abundant in vegetables and fruits. Vitamin $\mathrm{C}$ of cauliflower pickle was calculated by titration methods.

\section{Ash content}

The ash content of cauliflower pickle was calculated by muffle furnace using (AOAC 1990).

\section{pH}

$\mathrm{pH}$ is the measurement of the hydrogen ion concentration of a sample solution. It was calculated by digital $\mathrm{pH}$ meter using AOAC 1985.

\section{Total soluble solids (TSS)}

Total soluble solids (TSS) of cauliflower pickle in $\%$ or brix were determined by using a digital refractometer.

\section{Sensory evaluation}

Sensory analysis was performed in the Department of Processing and Food Engineering, at the College of Agricultural Engineering \& Technology (CAET), Dediapada. Panellists were selected on the basis of their ability to discriminate and a scale a broad range of different attributes. A semi-trained panel of 10 students and from faculty of the Agricultural Engineering and technology of CAET, Dediapada evaluated the cauliflower pickle products for appearance, aroma, taste, colour and overall acceptability on a 9-point hedonic scale. Different sample of cauliflower pickle (fresh, boiled, fried) were presented to panellists for sensory evaluation. Panellists were provided with a glass of water and were instructed to rinse and shallow water between samples. They were given written instruction and asked to evaluate the products for acceptability based on its appearance, aroma, taste, texture, color and overall acceptability using the nine points hedonic scale $(1=$ dislike extremely to $9=$ like extremely).

\section{Storage studies}

In storage studies pickles were stored in sealed in glass bottle at room temperature. The various properties like: $\mathrm{pH}$, TSS, appearance, aroma, colour, texture, taste, 
overall acceptability, colour change, off flavour and visual fungal growths for the different treatments of pickles were observed at a regular interval of one month up to three months storage period.

\section{Results and Discussion}

\section{Physico-chemical properties of cauliflower pickle}

Cauliflower pickles were prepared by fresh, boiling and frying of cauliflower with different combination of different spices. The prepared cauliflower pickles were packaged in air tight glass bottle. The results of the different physico-chemical properties such as moisture content of fresh cauliflower and cauliflower pickle, protein, vitamin $\mathrm{C}$, ash content, $\mathrm{pH}$ and TSS are presented in Table. 2 and discussed in the subsequent paragraphs.

\section{Moisture content}

Moisture content of fresh cauliflower and prepared cauliflower pickles were determined by hot air oven method. The result of the average value of moisture content of fresh cauliflower and prepared cauliflower pickles for different treatment were presented in Fig 3.1 .

From Fig. 3.1, it was observed the moisture content of cauliflower was varied in range of $87 \%$ to $94 \%$. The maximum moisture content $93.58 \%$ were found for fresh boiled cauliflower and the minimum moisture content $87.54 \%$ were found for fried cauliflower. It may be due to in boiling process some moisture were added and in frying process some moisture reduced. The moisture content of cauliflower pickles were varied in range of $40 \%$ to $59 \%$. The maximum values of moisture content $58.50 \%$ of cauliflower pickles was observed for treatment $\mathrm{T}_{5}$ and minimum values moisture content $40.56 \%$ was found for treatment $\mathrm{T}_{7}$. Usha et al., (1992) found that the safe moisture content in mango pickles to be as high as $61.0 \%$ which is closed to the result obtained for cauliflower pickles.

\section{Protein}

Different treatments of cauliflower pickles were prepared and protein content of pickles were analysed by Lowry method. Results of the average values in two replications were presented in Fig 3.2.

From Fig. 3.2, it was observed that when we increased the spices ingredients in pickles, the protein content for different treatments cauliflower pickle were increased. In cauliflower pickle the maximum protein contents was found $5.86 \mathrm{~g} / 100 \mathrm{~g}$ for treatment $\mathrm{T}_{8}$ and minimum protein content was found $4.97 \mathrm{~g} / 100 \mathrm{~g}$ for treatment $\mathrm{T}_{1}$. It may be due to addition of spices ingredients in the pickles.

\section{Vitamin C}

Different treatments of cauliflower pickles were prepared and Vitamin C content were analysed and determined by titration method. The results of different treatments in two replication and average values were presented in Fig 3.3.

From Fig. 3.3, it is clear that the maximum Vitamin C content was found $97.60 \mathrm{mg} / 100 \mathrm{~g}$ for treatment $\mathrm{T}_{6}$ and minimum Vitamin $\mathrm{C}$ content was found $91.37 \mathrm{mg} / 100 \mathrm{~g}$ for treatment $\mathrm{T}_{9}$.

\section{Ash content}

Ash content for different combinations of prepared cauliflower pickles were determined by muffle furnace. And the results of average values were presented in Fig 3.4. 
Table.1 Treatment details

\begin{tabular}{|c|c|c|c|c|}
\hline Sr. No. & Cauliflower Sample & Ingredients proportions & Product & Treatments \\
\hline 1. & \multirow[t]{3}{*}{$e^{2}$} & $\mathrm{~B}_{1}$ & $\mathrm{~A}_{1} \mathrm{~B}_{1}$ & $\mathrm{~T}_{1}$ \\
\hline 2. & & $\mathrm{~B}_{2}$ & $\mathrm{~A}_{1} \mathrm{~B}_{2}$ & $\mathrm{~T}_{2}$ \\
\hline 3. & & $\mathrm{~B}_{3}$ & $\mathrm{~A}_{1} \mathrm{~B}_{3}$ & $\mathrm{~T}_{3}$ \\
\hline 4. & \multirow{3}{*}{$\mathrm{A}_{2}$} & $\mathrm{~B}_{1}$ & $\mathrm{~A}_{2} \mathrm{~B}_{1}$ & $\mathrm{~T}_{4}$ \\
\hline 5. & & $\mathrm{~B}_{2}$ & $\mathrm{~A}_{2} \mathrm{~B}_{2}$ & $\mathrm{~T}_{5}$ \\
\hline 6. & & $\mathrm{~B}_{3}$ & $\mathrm{~A}_{2} \mathrm{~B}_{3}$ & $\mathrm{~T}_{6}$ \\
\hline 7. & \multirow{3}{*}{$\mathrm{A}_{3}$} & $\mathrm{~B}_{1}$ & $\mathrm{~A}_{3} \mathrm{~B}_{1}$ & $\mathrm{~T}_{7}$ \\
\hline 8. & & $\mathrm{~B}_{2}$ & $\mathrm{~A}_{3} \mathrm{~B}_{2}$ & $\mathrm{~T}_{8}$ \\
\hline 9. & & $\mathrm{~B}_{3}$ & $A_{3} B_{3}$ & $\mathrm{~T}_{9}$ \\
\hline
\end{tabular}

Table.2 Physico-chemical properties of cauliflower pickle

\begin{tabular}{|c|c|c|c|c|c|}
\hline Treatments & $\begin{array}{c}\text { M.C. (Fresh } \\
\text { Cauliflower), } \\
(\%)(w . b .)\end{array}$ & $\begin{array}{c}\text { M.C. } \\
\text { (Cauliflower } \\
\text { Pickle), } \\
(\%) \text { (w.b.) }\end{array}$ & $\begin{array}{l}\text { Protein } \\
\text { (g/100 g) }\end{array}$ & $\begin{array}{l}\text { Vitamin C } \\
(\mathrm{mg} / 100 \mathrm{~g})\end{array}$ & $\begin{array}{c}\text { Ash } \\
\text { content } \\
(\%)\end{array}$ \\
\hline $\mathbf{T}_{1}$ & 92.50 & 46.81 & 4.97 & 96.75 & $\underline{0.91}$ \\
\hline $\mathbf{T}_{2}$ & 92.50 & 44.71 & 5.11 & 96.95 & 1.12 \\
\hline $\mathbf{T}_{3}$ & 92.50 & 49.69 & 5.17 & 96.93 & 1.08 \\
\hline $\mathbf{T}_{4}$ & 93.58 & 57.96 & 4.37 & 97.33 & 2.48 \\
\hline $\mathbf{T}_{5}$ & 93.58 & $\underline{58.50}$ & 5.85 & 96.33 & 2.39 \\
\hline $\mathbf{T}_{6}$ & 93.58 & 54.19 & 5.48 & 97.60 & 3.03 \\
\hline $\mathbf{T}_{7}$ & 87.54 & $\underline{40.56}$ & 5.58 & 95.71 & 3.61 \\
\hline $\mathbf{T}_{8}$ & 87.54 & 42.22 & $\underline{5.86}$ & 95.70 & 3.04 \\
\hline $\mathbf{T}_{9}$ & 87.54 & 41.63 & 5.62 & 91.37 & $\underline{3.92}$ \\
\hline Mean & 91.21 & 48.47 & 5.33 & 96.07 & 2.40 \\
\hline CV (\%) & 0.07 & 18.29 & 0.62 & 21.09 & 1.49 \\
\hline SEM & 0.0262 & 10.2988 & 0.0224 & 10.7603 & 0.0209 \\
\hline CD at $5 \%$ & 0.0177 & 0.0115 & 0.0665 & 0.0997 & 0.0620 \\
\hline Test & Significant & Non Significant & Significant & Significant & Significant \\
\hline
\end{tabular}

Table.3 Variation in appearance of cauliflower pickles during storage periods

\begin{tabular}{|c|c|c|r|r|r|}
\hline \multirow{2}{*}{ Sr. No. } & Treatments & \multicolumn{4}{|c|}{ Appearance } \\
\cline { 3 - 6 } & & 0 Months & 1 Month & 2 Months & 3 Months \\
\hline $\mathbf{1 .}$ & $\mathrm{T}_{1}$ & 6.37 & 6.92 & 6.42 & 4.06 \\
\hline $\mathbf{2 .}$ & $\mathrm{T}_{2}$ & 6.82 & 6.51 & 6.65 & 4.11 \\
\hline $\mathbf{3 .}$ & $\mathrm{T}_{3}$ & 7.02 & 6.81 & 6.52 & 4.03 \\
\hline $\mathbf{4 .}$ & $\mathrm{T}_{4}$ & 6.94 & 6.72 & 6.11 & 4.15 \\
\hline $\mathbf{5 .}$ & $\mathrm{T}_{5}$ & 6.42 & 6.76 & 6.34 & 4.02 \\
\hline $\mathbf{6 .}$ & $\mathrm{T}_{6}$ & 6.8 & 6.84 & 7.21 & 3.80 \\
\hline $\mathbf{7 .}$ & $\mathrm{T}_{7}$ & 6.02 & 6.63 & 6.38 & 5.15 \\
\hline $\mathbf{8 .}$ & $\mathrm{T}_{8}$ & 6.91 & 7.02 & 6.24 & 4.28 \\
\hline $\mathbf{9 .}$ & $\mathrm{T}_{9}$ & 6.57 & 6.42 & 7.01 & 4.20 \\
\hline
\end{tabular}


Table.4 Variation in aroma of cauliflower pickles during storage periods

\begin{tabular}{|c|c|c|r|r|r|}
\hline \multirow{2}{*}{ Sr. No. } & \multirow{2}{*}{ Treatments } & \multicolumn{4}{|c|}{ Aroma } \\
\cline { 3 - 6 } & & O Months & $\mathbf{1}$ Month & 2 Months & 3 Months \\
\hline $\mathbf{1 .}$ & $\mathrm{T}_{1}$ & 6.87 & 6.91 & 6.31 & 4.04 \\
\hline $\mathbf{2 .}$ & $\mathrm{T}_{2}$ & 6.56 & 7.07 & 6.14 & 4.31 \\
\hline $\mathbf{3 .}$ & $\mathrm{T}_{3}$ & 6.52 & 6.91 & 6.41 & 4.09 \\
\hline $\mathbf{4 .}$ & $\mathrm{T}_{4}$ & 6.63 & 6.94 & 6.36 & 4.73 \\
\hline $\mathbf{5 .}$ & $\mathrm{T}_{5}$ & 6.82 & 7.07 & 6.84 & 4.55 \\
\hline $\mathbf{6 .}$ & $\mathrm{T}_{6}$ & 6.41 & 7.11 & 7.12 & 4.07 \\
\hline $\mathbf{7 .}$ & $\mathrm{T}_{7}$ & 6.11 & 7.09 & 6.61 & 5.35 \\
\hline $\mathbf{8 .}$ & $\mathrm{T}_{8}$ & 7.16 & 6.94 & 6.62 & 4.00 \\
\hline $\mathbf{9 .}$ & $\mathrm{T}_{9}$ & 6.62 & 5.81 & 7.42 & 4.08 \\
\hline
\end{tabular}

Table.5 Variation in texture of cauliflower pickles during storage periods

\begin{tabular}{|c|c|c|r|r|r|}
\hline \multirow{2}{*}{ Sr. No. } & \multirow{2}{*}{ Treatments } & \multicolumn{4}{|c|}{ Texture } \\
\cline { 3 - 6 } & & O Months & 1 Month & 2 Months & 3 Months \\
\hline 1. & $\mathrm{T}_{1}$ & 6.21 & 6.94 & 6.74 & 4.01 \\
\hline $\mathbf{2 .}$ & $\mathrm{T}_{2}$ & 6.42 & 6.91 & 6.25 & 4.46 \\
\hline $\mathbf{3 .}$ & $\mathrm{T}_{3}$ & 7.01 & 7.54 & 7.09 & 3.97 \\
\hline $\mathbf{4 .}$ & $\mathrm{T}_{4}$ & 6.91 & 6.71 & 6.79 & 4.09 \\
\hline $\mathbf{5 .}$ & $\mathrm{T}_{5}$ & 6.14 & 6.75 & 6.61 & 4.85 \\
\hline $\mathbf{6 .}$ & $\mathrm{T}_{6}$ & 6.41 & 7.21 & 7.21 & 4.29 \\
\hline $\mathbf{7 .}$ & $\mathrm{T}_{7}$ & 6.66 & 6.84 & 6.01 & 5.05 \\
\hline $\mathbf{8 .}$ & $\mathrm{T}_{8}$ & 6.81 & 6.52 & 6.25 & 4.33 \\
\hline $\mathbf{9 .}$ & $\mathrm{T}_{9}$ & 6.54 & 6.21 & 6.25 & 3.84 \\
\hline
\end{tabular}

Table.6 Variation in taste of cauliflower pickles during storage periods

\begin{tabular}{|c|c|c|r|r|r|}
\hline \multirow{2}{*}{ Sr. No. } & \multirow{2}{*}{ Treatments } & \multicolumn{4}{|c|}{ Taste } \\
\cline { 3 - 6 } & & O Months & 1 Month & 2 Months & 3 Months \\
\hline $\mathbf{1 .}$ & $\mathrm{T}_{1}$ & 5.83 & 6.27 & 6.42 & 4.08 \\
\hline $\mathbf{2 .}$ & $\mathrm{T}_{2}$ & 5.56 & 6.45 & 6.45 & 4.17 \\
\hline $\mathbf{3 .}$ & $\mathrm{T}_{3}$ & 6.13 & 6.61 & 6.90 & 4.11 \\
\hline $\mathbf{4 .}$ & $\mathrm{T}_{4}$ & 5.91 & 6.84 & 6.84 & 3.95 \\
\hline $\mathbf{5 .}$ & $\mathrm{T}_{5}$ & 6.24 & 6.94 & 7.31 & 4.23 \\
\hline $\mathbf{6 .}$ & $\mathrm{T}_{6}$ & 7.17 & 7.02 & 6.92 & 3.75 \\
\hline $\mathbf{7 .}$ & $\mathrm{T}_{7}$ & 5.8 & 7.55 & 6.71 & 3.29 \\
\hline $\mathbf{8 .}$ & $\mathrm{T}_{8}$ & 7.26 & 6.83 & 6.82 & 4.05 \\
\hline $\mathbf{9 .}$ & $\mathrm{T}_{9}$ & 6.33 & 5.70 & 7.42 & 4.31 \\
\hline
\end{tabular}


Table.7 Variation in colour of cauliflower pickles during storage periods

\begin{tabular}{|c|c|c|r|r|r|}
\hline \multirow{2}{*}{ Sr. No. } & \multirow{2}{*}{ Treatments } & \multicolumn{4}{|c|}{ Colour } \\
\cline { 3 - 6 } & & O Months & $\mathbf{1}$ Month & $\mathbf{2}$ Months & 3 Months \\
\hline $\mathbf{1 .}$ & $\mathrm{T}_{1}$ & 6.13 & 6.57 & 6.93 & 3.85 \\
\hline $\mathbf{2 .}$ & $\mathrm{T}_{2}$ & 6.50 & 6.71 & 6.71 & 4.05 \\
\hline $\mathbf{3 .}$ & $\mathrm{T}_{3}$ & 7.24 & 7.12 & 6.63 & 3.56 \\
\hline $\mathbf{4 .}$ & $\mathrm{T}_{4}$ & 7.42 & 7.15 & 6.73 & 5.02 \\
\hline $\mathbf{5 .}$ & $\mathrm{T}_{5}$ & 6.70 & 7.22 & 7.14 & 4.19 \\
\hline $\mathbf{6 .}$ & $\mathrm{T}_{6}$ & 6.56 & 6.51 & 7.24 & 4.00 \\
\hline $\mathbf{7 .}$ & $\mathrm{T}_{7}$ & 6.32 & 6.77 & 7.24 & 4.89 \\
\hline $\mathbf{8 .}$ & $\mathrm{T}_{8}$ & 6.82 & 6.32 & 6.84 & 3.77 \\
\hline $\mathbf{9 .}$ & $\mathrm{T}_{9}$ & 6.61 & 6.44 & 6.53 & 4.25 \\
\hline
\end{tabular}

Table.8 Variation in overall acceptability of cauliflower pickles during storage periods

\begin{tabular}{|c|c|c|c|c|c|}
\hline \multirow{2}{*}{ Sr. No. } & \multirow{2}{*}{ Treatments } & \multicolumn{4}{|c|}{ Overall acceptability } \\
\cline { 3 - 6 } & & O Months & 1 Month & 2 Months & 3 Months \\
\hline $\mathbf{1 .}$ & $\mathrm{T}_{1}$ & 6.28 & 6.72 & 6.43 & 5.52 \\
\hline $\mathbf{2 .}$ & $\mathrm{T}_{2}$ & 6.37 & 6.73 & 6.50 & 4.14 \\
\hline $\mathbf{3 .}$ & $\mathrm{T}_{3}$ & 6.78 & 6.99 & 6.72 & 3.26 \\
\hline $\mathbf{4 .}$ & $\mathrm{T}_{4}$ & 6.76 & 6.87 & 6.45 & 5.68 \\
\hline $\mathbf{5 .}$ & $\mathrm{T}_{5}$ & 6.46 & 6.94 & 6.91 & 6.04 \\
\hline $\mathbf{6 .}$ & $\mathrm{T}_{6}$ & 6.67 & 6.93 & 7.06 & 3.95 \\
\hline $\mathbf{7 .}$ & $\mathrm{T}_{7}$ & 6.18 & 6.97 & 6.73 & 4.25 \\
\hline $\mathbf{8 .}$ & $\mathrm{T}_{8}$ & 6.99 & 6.72 & 6.75 & 5.13 \\
\hline $\mathbf{9 .}$ & $\mathrm{T}_{9}$ & 6.53 & 5.99 & 7.25 & 3.71 \\
\hline
\end{tabular}

Table.9 Storage studies of cauliflower pickles for the period of 0 months

\begin{tabular}{|c|c|c|c|c|c|}
\hline Treatments & $\begin{array}{c}\text { Colour } \\
\text { change }\end{array}$ & $\begin{array}{c}\text { Off } \\
\text { flavour }\end{array}$ & Texture & $\begin{array}{c}\text { Visual } \\
\text { fungal } \\
\text { growth }\end{array}$ & Remark \\
\hline $\mathbf{T}_{\mathbf{1}}$ & No & No & Firm & No & Good \\
\hline $\mathbf{T}_{\mathbf{2}}$ & No & No & Firm & No & Good \\
\hline $\mathbf{T}_{\mathbf{3}}$ & No & No & Firm & No & Good \\
\hline $\mathbf{T}_{\mathbf{4}}$ & No & No & Slightly soft & No & Good \\
\hline $\mathbf{T}_{\mathbf{5}}$ & No & No & Firm & No & Good \\
\hline $\mathbf{T}_{\mathbf{6}}$ & No & No & Firm & No & Good \\
\hline $\mathbf{T}_{\mathbf{7}}$ & No & No & Firm & No & Good \\
\hline $\mathbf{T}_{\mathbf{8}}$ & No & No & Firm & No & Good \\
\hline $\mathbf{T}_{\mathbf{9}}$ & No & No & Firm & No & Good \\
\hline
\end{tabular}


Table.10 Storage studies of cauliflower pickles for the period of 1 month

\begin{tabular}{|c|c|c|c|c|c|}
\hline Treatments & $\begin{array}{c}\text { Colour } \\
\text { change }\end{array}$ & $\begin{array}{c}\text { Off } \\
\text { flavour }\end{array}$ & Texture & $\begin{array}{c}\text { Visual } \\
\text { fungal } \\
\text { growth }\end{array}$ & Remark \\
\hline $\mathbf{T}_{\mathbf{1}}$ & No & No & Firm & No & Good \\
\hline $\mathbf{T}_{\mathbf{2}}$ & No & No & Slightly soft & No & Good \\
\hline $\mathbf{T}_{\mathbf{3}}$ & No & No & Slightly soft & No & Good \\
\hline $\mathbf{T}_{\mathbf{4}}$ & No & No & Slightly soft & No & Good \\
\hline $\mathbf{T}_{\mathbf{5}}$ & No & No & Firm & No & Good \\
\hline $\mathbf{T}_{\mathbf{6}}$ & No & No & Firm & No & Good \\
\hline $\mathbf{T}_{\mathbf{7}}$ & No & No & Soft & No & Good \\
\hline $\mathbf{T}_{\mathbf{8}}$ & No & No & Firm & No & Good \\
\hline $\mathbf{T}_{\mathbf{9}}$ & No & No & Firm & No & Good \\
\hline
\end{tabular}

Table.11 Storage studies of cauliflower pickles for the period of 2 months

\begin{tabular}{|c|c|c|c|c|c|}
\hline Treatments & $\begin{array}{c}\text { Colour } \\
\text { change }\end{array}$ & $\begin{array}{c}\text { Off } \\
\text { flavour }\end{array}$ & Texture & $\begin{array}{c}\text { Visual } \\
\text { fungal } \\
\text { growth }\end{array}$ & Remark \\
\hline $\mathbf{T}_{\mathbf{1}}$ & No & No & Slightly Soft & No & Good \\
\hline $\mathbf{T}_{\mathbf{2}}$ & No & No & soft & No & Good \\
\hline $\mathbf{T}_{\mathbf{3}}$ & No & No & soft & No & Good \\
\hline $\mathbf{T}_{\mathbf{4}}$ & No & Slightly & Soft & No & Good \\
\hline $\mathbf{T}_{\mathbf{5}}$ & No & No & Slightly Soft & No & Good \\
\hline $\mathbf{T}_{\mathbf{6}}$ & No & No & Slightly soft & No & Good \\
\hline $\mathbf{T}_{\mathbf{7}}$ & No & Slightly & soft & Slightly & Slightly \\
\hline & & & spoiled \\
\hline $\mathbf{T}_{\mathbf{8}}$ & No & No & Firm & No & Good \\
\hline $\mathbf{T}_{\mathbf{9}}$ & No & No & Firm & No & Good \\
\hline
\end{tabular}

Table.12 Storage studies of cauliflower pickles for the period of 3 months

\begin{tabular}{|c|c|c|c|c|c|}
\hline Treatments & $\begin{array}{c}\text { Colour } \\
\text { change }\end{array}$ & $\begin{array}{c}\text { Off } \\
\text { flavour }\end{array}$ & Texture & $\begin{array}{c}\text { Visual fungal } \\
\text { growth }\end{array}$ & Remark \\
\hline $\mathbf{T}_{\mathbf{1}}$ & No & No & Soft & No & Good \\
\hline $\mathbf{T}_{\mathbf{2}}$ & No & Slightly & Soft & No & Good \\
\hline $\mathbf{T}_{\mathbf{3}}$ & Yes & No & Soft & Yes & Slightly spoiled \\
\hline $\mathbf{T}_{\mathbf{4}}$ & Yes & Slightly & Soft & No & Good \\
\hline $\mathbf{T}_{\mathbf{5}}$ & Yes & Slightly & Slightly soft & No & Good \\
\hline $\mathbf{T}_{\mathbf{6}}$ & No & No & Slightly soft & No & Good \\
\hline $\mathbf{T}_{\mathbf{7}}$ & Yes & Slightly & Soft & Yes & Slightly spoiled \\
\hline $\mathbf{T}_{\mathbf{8}}$ & No & No & Slightly soft & No & Good \\
\hline $\mathbf{T}_{\mathbf{9}}$ & No & Slightly & Slightly soft & No & Good \\
\hline
\end{tabular}


Plate.2.1 sensory evaluation

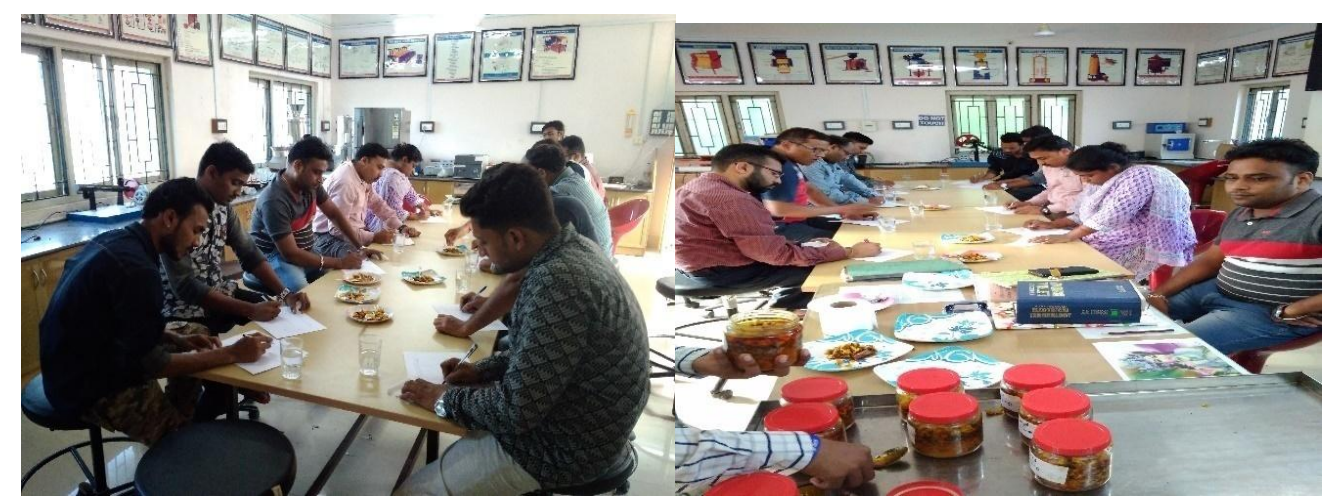

Plate.2.2 Storage studies

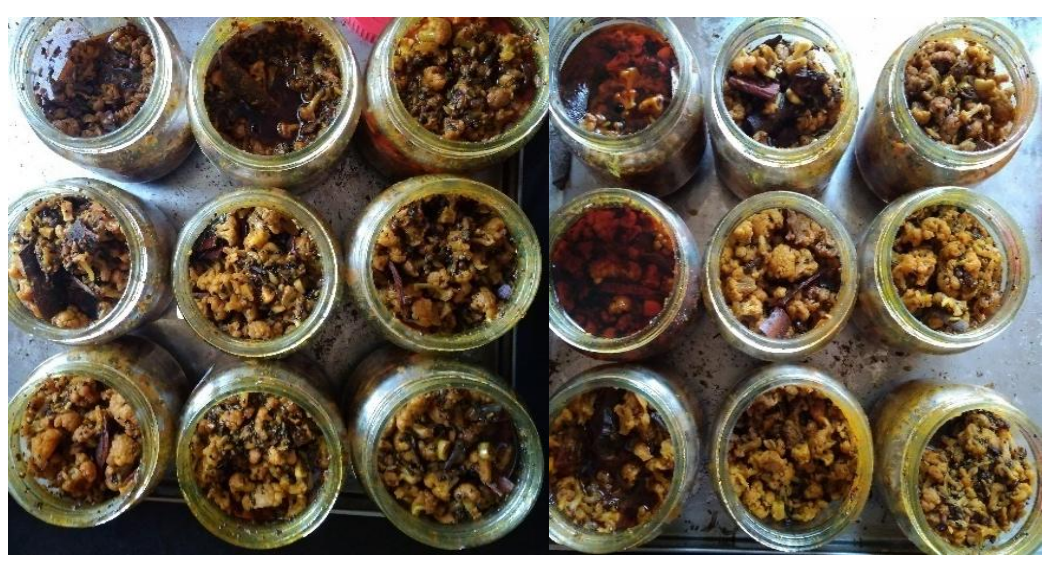

Fig.1 Moisture content of fresh cauliflower and cauliflower pickles

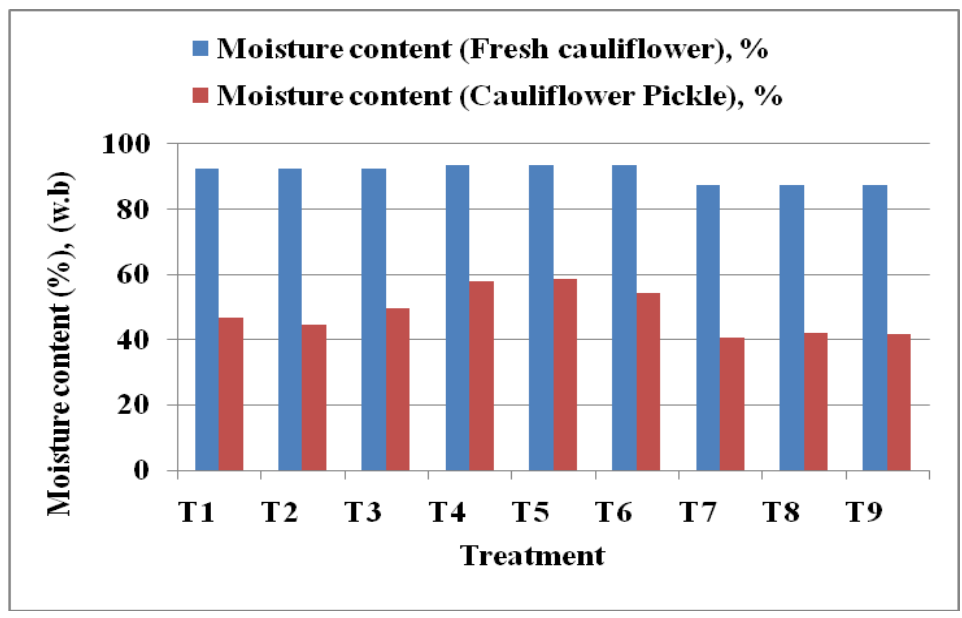


Fig.2 Protein content of cauliflower pickles

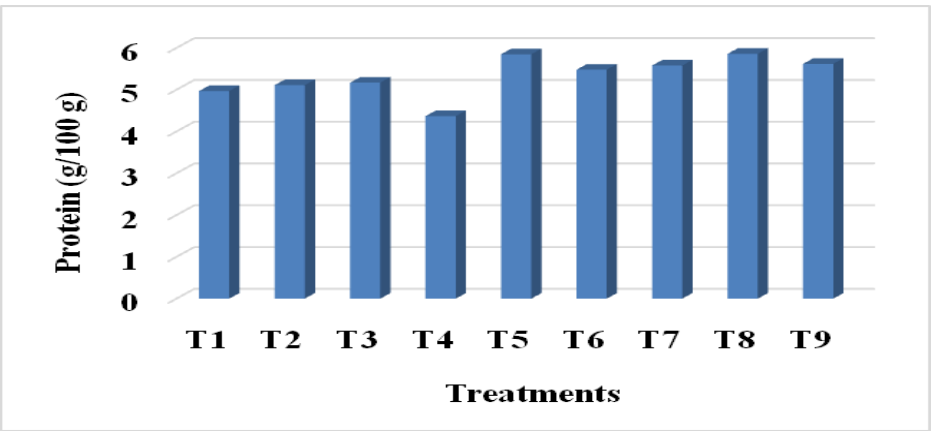

Fig.3 Vitamin C content of cauliflower Pickles

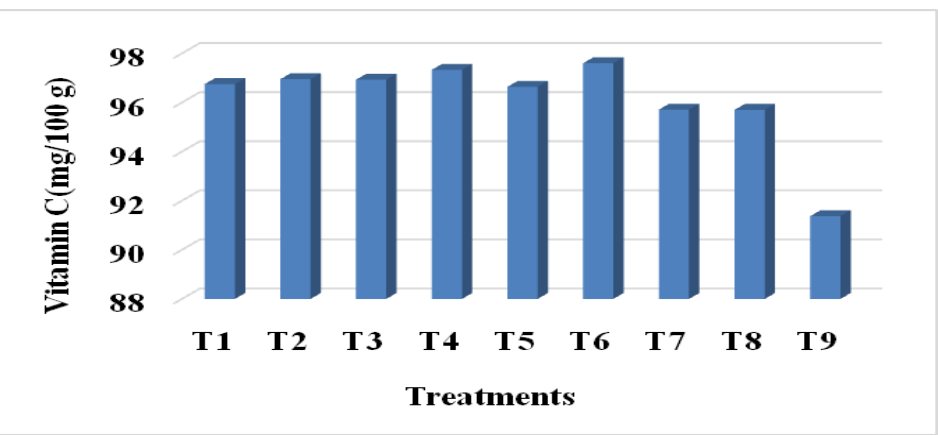

Fig.4 Ash content of cauliflower pickles

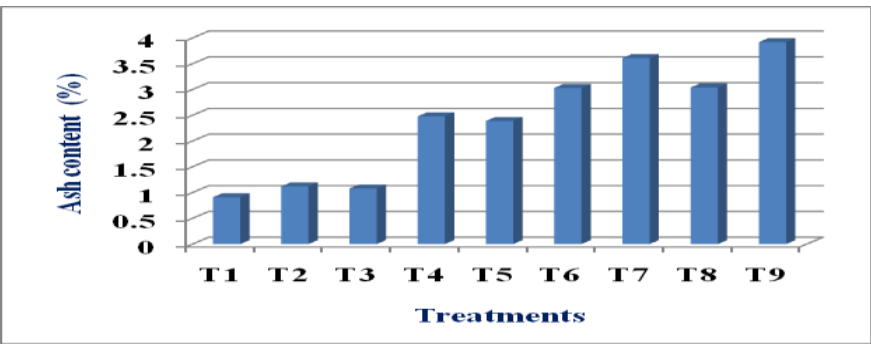

Fig.5 $\mathrm{pH}$ value of cauliflower pickles during storage periods

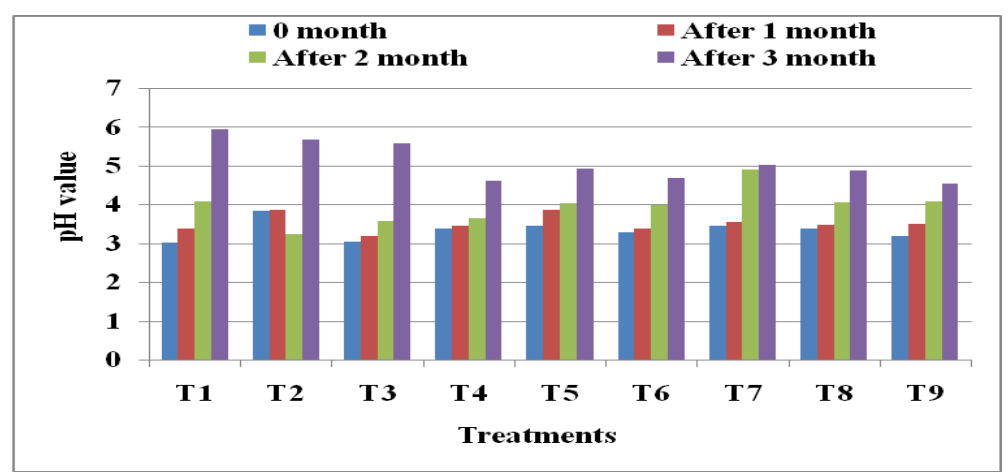


Fig.6 TSS of cauliflower pickles during storage periods

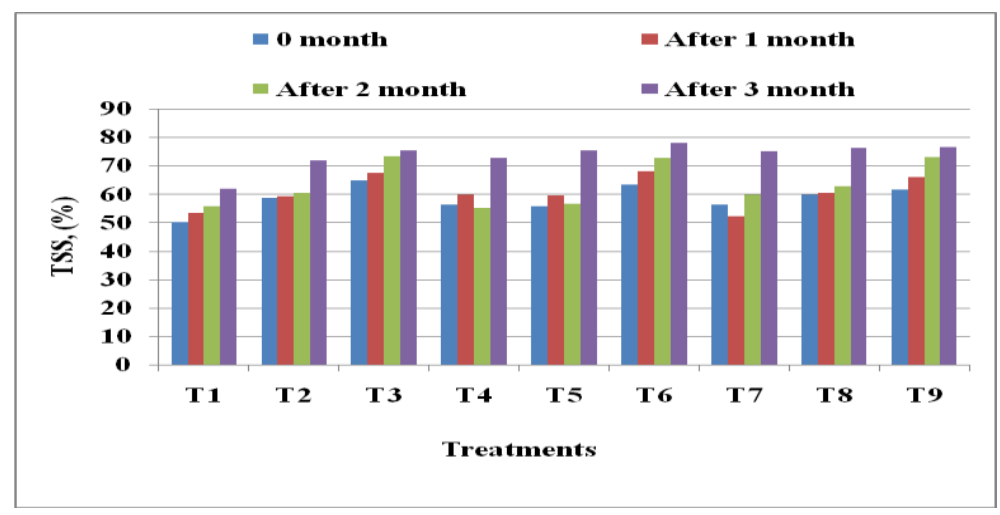

From Fig.4, it was found that the when we increased the spices ingredients in the fresh, boiled and fried pickles, then the ash content of pickles were found increased. In cauliflower pickles the maximum ash content was reported $3.92 \%$ for treatment $\mathrm{T}_{9}$ and minimum ash content was found $0.91 \%$ for treatment $T_{1}$. The cause of increasing ash content may be the use of various types of spices in the treatments.

\section{pH}

The $\mathrm{pH}$ values of prepared pickles were determined by digital $\mathrm{pH}$ meter and average values of results were presented in Fig.5.

From Fig.5, it was reported that the three months of storage, a increasing trend of $\mathrm{pH}$ value with the increase duration of storage period was observed. Higher $\mathrm{pH}$ value 5.93 was reported significant for $T_{1}$ treatments for three months of storage periods whereas lower $\mathrm{pH}$ values 3.01 were observed significant for $T_{1}$ treatments for zero months of storage periods. The phenomenon might be possible due to oxidation of acid during storage resulting in higher $\mathrm{pH}$ values.

\section{Total soluble solids (TSS)}

Total soluble solids of prepared cauliflower pickles were determined by and hand operated digital refractometer and average values of results were presented in Fig.6.

From Fig.6, it is highly variation was observed for TSS content between treatments during different storage month. The results exhibited that TSS content of cauliflower pickle developed in a continuous significantly higher with the expansion of storage period. The higher percentage of TSS during storage of cauliflower pickle was noted $78.00 \%$ for treatment $\mathrm{T}_{6}$ from third month after storage and lower TSS value was noted $50.10 \%$ for treatment $\mathrm{T}_{1}$ from zero month after storage. The TSS value of pickles were increased during storage period of time, it may be possible that the sugar and salt were mixed well and properly.

\section{Sensory evaluation properties}

The prepared cauliflower pickles of different treatments were presented to the panellists and asked to give score for appearance, aroma, texture, taste, colour and overall acceptability as per 9-point hedonic scale. The results of sensory evaluation of different treatments of cauliflower pickles for different storage periods were presented in Table 3 to 8 and discussed in the subsequent headings.

Table 3 to 8 , shows the significant variation were observed for appearance, aroma, texture, 
taste, colour and overall acceptability. It also shows the sensory values for all properties were more than 5.00 up to 2 months storage periods whereas after 3 months storage periods some values of sensory scores were found below 5.00 except $\mathrm{T}_{1}, \mathrm{~T}_{4}, \mathrm{~T}_{5}, \mathrm{~T}_{7}$, and $\mathrm{T}_{8}$.

\section{Storage studies}

Cauliflower pickles were prepared with different combinations of spices ingredients. Nine different treatments of cauliflower pickles were used for storage studies at room temperature $\left(27^{\circ} \mathrm{C}\right.$ to $\left.33^{\circ} \mathrm{C}\right)$ up to 3 months at one month interval. The effect of storage period i.e. $0,1,2$ and 3 months on colour change, off flavour, texture and visual fungal growth of the pickles were observed.

\section{Storage studies of cauliflower pickles during storage period for 0 months}

The effect of storage time during 0 months on colour change, off flavour and texture and visual fungal growth of the pickles were studied and shown in Table 9.

Table 3.1 shows that storage studies for 0 months period on colour change, off flavour, visual fungal growth of cauliflower pickle were are not change for all the treatments. And for the texture, the only treatment $\mathrm{T}_{4}$ was found slightly soft while others treatment found firm. All the cauliflower pickle treatments were found good in good condition.

\section{Storage studies of cauliflower pickles} during storage period for 1 month

The effect of storage time during 1 month on colour change, off flavour and texture and visual fungal growth of the pickles were studied and shown in Table 10.
Table 10 shows that storage studies for the period of 1 month on colour changed, off flavour properties and visual fungal growth of cauliflower pickle were are not change for all the treatments, whereas for the texture, the treatment $T_{2}, T_{3}$, and $T_{4}$ were found slightly soft while others treatment found firm. All the cauliflower pickle treatments were found good in good condition.

\section{Storage studies of cauliflower pickles during storage period for 2 months}

The effect of storage time during 2 months on colour change, off flavour and texture and visual fungal growth of the pickles were studied and shown in Table 11.

Table 3.3 shows that storage studies for the period of 2 months on colour change properties were not change while off flavour properties and visual fungal growth of cauliflower pickles were changed for treatments $T_{4}$ and $T_{7}$ respectively. For the texture most of the treatments were found slightly soft and soft, except the treatment $\mathrm{T}_{8}$ $\& \mathrm{~T}_{9}$. All the cauliflower pickle treatments were found good only treatment $\mathrm{T}_{7}$ was found slightly spoiled.

\section{Storage studies of cauliflower pickles during storage period for 3 months}

The effect of storage time during 3 months on colour change, off flavour and texture and visual fungal growth of the pickles were studied and shown in Table 12.

Table 3.4 shows that storage studies of cauliflower pickles for the period of 3 months, the colour change were observed for treatments $\mathrm{T}_{3}, \mathrm{~T}_{4}, \mathrm{~T}_{5}, \mathrm{~T}_{7}$, whereas slightly off flavour properties were observed for treatments $\mathrm{T}_{2}, \mathrm{~T}_{4}, \mathrm{~T}_{5}, \mathrm{~T}_{7}$ and $\mathrm{T}_{9}$. The visual fungal growths of cauliflower pickle were reported for treatments $T_{3}$ and $T_{7}$ and for the 
texture most of the treatments were found slightly soft and soft. All the cauliflower pickle treatments were found good condition except the treatments $T_{3}$ and $T_{7}$ which was found slightly spoiled.

In conclusion the physico-chemical properties like- moisture content, protein content, vitamin $\mathrm{C}$, ash content, $\mathrm{pH}$ value, TSS value and sensory evaluation like- appearance, aroma, texture, taste, colour, overall acceptability and storage studied like- colour change, off flavour, texture, visual fungal growth of cauliflower pickle were studied. On the basis of overall studied we can says or recommend the treatment $\mathrm{T}_{8}$ was found best followed by treatment $\mathrm{T}_{9}, \mathrm{~T}_{6}$ and $\mathrm{T}_{5}$. Thus we can says the cauliflower pickles prepared by frying in mustard oil or boiling in water and different composition of spices i.e. $250 \mathrm{gm}$ cauliflower, $50 \mathrm{~g}$ of salt, $9 \mathrm{~g}$ ginger, $9 \mathrm{~g}$ red chili powder, $8 \mathrm{~g}$ cinnamon, $5 \mathrm{~g}$ cumin, $4 \mathrm{~g}$ cardamom, $11 \mathrm{~g}$ aniseed, $4 \mathrm{~g}$ clove, $16 \mathrm{~g}$ mustard, $40 \mathrm{~g}$ vinegar, $45 \mathrm{~g}$ sugar, $100 \mathrm{ml}$ mustard oil, $12 \mathrm{~g}$ garlic were added and mix well.

\section{References}

A.O.A.C., 1990. Official Methods of Analysis. 15th ed., Association of Official Analytical

Chemists.Washington, DC.

Arghya Mani (2017). Studies on Sodium Substitution in Mango Pickle. Master of Science (Horticulture) Thesis Submitted to Department of Pomology and Post Harvest Technology, Faculty of Horticulture Uttar Banga Krishi Viswavidyalaya, Pundibari-736165, Coochbehar, West Bengal.

Berrang ME, Brackett RE, Beuchat LR (1990). Microbial, color and textural qualities of fresh asparagus, broccoli, and cauliflower stored under controlled atmosphere. J. Food Protect. 53: 391-
395.

Canan Ece Tamer (2012). Quality evaluation of canned cauliflower pickles prepared with different ingredients. African Journal of Agricultural Research Vol. 7(10), pp. 1550-1555. DOI: 10.5897/AJAR11.1474.

DeEll JR, Toivonen PMA, Doussineau J, Roger C, Vigneault C (2003). Effect of different methods for application of an antifog shrink film to maintain cauliflower quality during storage. $\mathrm{J}$. Food Qual., 26: 211-218.

FAO, Fermented Fruits and Vegetables-A Global Perspective, vol.134, FAO Agricultural Services Bulletin, Rome, Italy, 1998.

Fjeldsenden B, Martens M, Russwurm JH (1981). Sensory quality criteria of carrots, swedes and cauliflower. Lebensm.-Wiss. u.-Technol.14: 237-241. Forbes JJ, Chapman KSR (1989). Field protection of cauliflower curds to preserve whiteness and improve postharvest quality. Acta Hort. 247: 337341.

Gopal TKS; Balachandran KK; Surendran PK; Govindan TK, Development of flexible packagings for mussel pickled in oil. In: Harvest and post-harvest technology of fish. Pg. 744. C. Chellaram (2015). Chemical composition, shelf-life studies and popularization on Pleuroploca trapezium meat pickle. Journal of Chemical and Pharmaceutical Research, 7(1):25-30.

Hardenburg RE, Watada AE, Wang CY (1986). The commercial storage of fruits, vegetables, and florist and nursery stocks, pp. 55. United States Department of Agriculture, Agricultural Handbook 66 (revised).

Hodges DM, Munro KD, Forney CF, McRae KB (2006). Glucosinolate and free sugar content in cauliflower (Brassica oleracea var. botrytis cv. Freemont) during 
controlled-atmosphere

storage.

Postharvest Biol. Technol., 40: 123-132.

Jamshidi, A; Kazerani, H.R.; Seifi, H.A. and Moghaddas, E. (2008). Growth limits of Staphylococcus aureus as a function of temperature, acetic acid, $\mathrm{NaCl}$ concentration and inoculum level. Iranian Journal Veterinary Research. 9:353-359.

Kaur, C. and Kapoor, H.C. (2001). Antioxidant activity and quality of minimally processed Indian Cabbage (Brassica oleracea var. Capitata). Journal of Food Processing and Preservation 25(5): 367-380.

Madavi Shivkumar and Bhajbhuje MN (2014) Biodiversity of seed borne microfungal flora in storage on cauliflower (Brassica oleracea var. botrytis) from Nagpur region., Int. J. of Life Sciences, Special issue A2: 43-47.

Nishina, A., Kuboto, K., Kameoka, H. and Osawa, T. (1991). Antioxidising component, musizin, in Rumex japonicus. Houtt. Journal of American Oil Chemists Society 68: 735-739.

Noor, F., Aktar, T.S., Mahomud, M.S., and M.M Islam.(2014). Impact of processing method on quality of cauliflower Pickle. Journal of Science and Technology 12: 48-53.

Nurul, S.R., Asmah, R. (2012): Evaluation of an-tioxidant properties in fresh and pickled pa-payaInternational. Food Research Journal, 19(3): 1117-1124.

Sauberlich, H.E. (1994). Pharmocology of vitamin C. Annu. Rev. Nutr. 14: 371-391.

Scalzo RL, Bianchi G, Genna A, Suma C (2007). Antioxidant properties and lipidic profile as quality indexes of cauliflower (Brassica oleracea L. var. botrytis) in relation to harvest time. Food Chem., 100: 1019-1025.

Scalzo RL, Bianchi G, Genna A, Suma C (2007). Antioxidant properties and lipidic profile as quality indexes of cauliflower (Brassica oleracea L. var. botrytis) in relation to harvest time. Food Chem., 100: 1019-1025.

Schonhof I, Krumbein A, Bruckner B (2004). Genotypic effects on glucosinolates and sensory properties of broccoli and cauliflower. Nahrung-Food. 48: 25-33.

Sharma SR, Singh PK, Chable V, Tripathi SK (2005). A review of hybrid cauliflower development. J. New Seeds, 6(2): 151193.

Suslow TV, Cantwell M (1998). Cauliflower: Recommendations for maintaining postharvest quality. Perishables Handling Quart., 93:13-14.

USDA, ERS (2007). Commodity highlight: Pickling cucumbers. Vegetables and Melons Outlook, , 24-30.

Usha RM, R Rao S N, Giria Bai R, Nagaraja KV. 1992. Studies on quality standards of Indian commercial pickle. Indian Food Packer. India. 46(6): 27-33.

Wargovich, MJ. (2000). Anticancer properties of fruits and vegetables. Hort. Science 35: 573-575.

Yamano, T., Lino, H., Takada, M., Blum, S., Ro-chat, F., Fukushima, Y. (2006): Improvement of the human intestinal flora by ingestion of the probiotic strain Lactobacillus johnsonii La1. British Journal of Nutrition, 95(2): 303-312.

\section{How to cite this article:}

Singh, S. N., V. A. Patel, M. G. Varma, S. G. Patel and Savaliya, M. V. 2021. Effect of Processing Methods on Physico-Chemical Properties, Sensory Evaluations and Storage Studies of Cauliflower (Brassica oleracea L. var. botrytis) Pickle. Int.J.Curr.Microbiol.App.Sci. 10(01): 1413-1428. doi: https://doi.org/10.20546/ijcmas.2021.1001.168 